\begin{tabular}{|l|l|l||}
\hline \multicolumn{2}{|c|}{ PublisherInfo } \\
\hline \hline PublisherName & $:$ & BioMed Central \\
\hline \hline PublisherLocation & $:$ & London \\
\hline \hline PublisherImprintName & $:$ & BioMed Central \\
\hline \hline
\end{tabular}

\title{
Yeasts: the basis for new vaccines
}

\begin{tabular}{||l|l|l||}
\hline \multicolumn{2}{|c||}{ ArticleInfo } \\
\hline \hline ArticleID & $:$ & 4074 \\
\hline \hline ArticleDOI & $:$ & $10.1186 /$ gb-spotlight-20010503-01 \\
\hline \hline ArticleCitationID & $:$ & spotlight-20010503-01 \\
\hline \hline ArticleSequenceNumber & $:$ & 145 \\
\hline \hline ArticleCategory & $:$ & Research news \\
\hline ArticleFirstPage & $:$ & 1 \\
\hline \hline ArticleLastPage & $:$ & 2 \\
\hline \hline & & RegistrationDate : 2001-05-03 \\
ArticleHistory & $:$ & OnlineDate $\quad$ 2001-05-03 \\
\hline \hline ArticleCopyright & $:$ & BioMed Central Ltd2001 \\
\hline \hline ArticleGrants & $:$ & \\
\hline \hline ArticleContext & $:$ & 130592211 \\
\hline \hline
\end{tabular}




\section{Tudor Toma}

Email: ttoma@mail.dntis.ro

Efficient cell-mediated immunity requires the activation of dendritic cells (DC). Currently there is a great deal of interest in vaccine strategies that employ DC immunostimulatory complexes. In the May issue of Nature Medicine, Andrew Stubbs and colleagues from the University of Colorado Health Sciences Center, Denver, suggest that genetically engineered yeast may be capable of acting as an immunostimulatory complex.

Stubbs et al. demonstrate that recombinant Saccharomyces cerevisiae engineered to express tumor or HIV-1 antigens are capable of eliciting cytotoxic T lymphocyte-mediated responses and protective immunity in mice. Interactions between yeast and DCs led to DC maturation, IL-12 production and the efficient priming of MHC class I- and class II-restricted, antigen-specific T-cell responses (Nat Med 2001, 7:625-629).

Yeast also exerted a strong adjuvant effect, augmenting DC presentation of the exogenous wholeprotein antigen to MHC class I- and class II-restricted T cells. This suggests that recombinant yeast may be a good candidate for the development of a vaccine-mediated strategy to induce efficient and long lasting cellular immune responses.

\section{References}

1. Stubbs AC, Martin KS, Coeshott C, Skaates SV, Kuritzkes DR, Bellgrau D, Franzosoff A, Duke RC, Wilson CC: Whole recombinant yeast vaccine activates dendritic cells and elicits protective cellmediated immunity. Nat Med 2001, 7:625-629., [http://www.nature.com/nm]

2. University of Colorado Health Sciences Center, [http://www.uchsc.edu/home/] 